\title{
Composite synthetic hydroxyapatite $30 \%$, in two physical states, as dermal filler
}

\author{
Rodrigo Viana Sepúlveda ${ }^{1}$, Andréa Pacheco Batista Borges ${ }^{2}$, Lissandro Gonçalves Conceição ${ }^{2}$ \\ Fabrício Luciani Valente ${ }^{2}$ Emily Correna Carlo Reis ${ }^{2}$, Ingrid Bitencourt Bohnenberger ${ }^{1}$
}

\begin{abstract}
The aim of this study was to evaluate the response to the implantation of synthetic hydroxyapatite $30 \%$ (HAP-9 ${ }^{\circledR}$ ) in different physical states as dermal filler. Eighteen New Zealand rabbits were used, distributed randomly into two equal groups and then divided into three groups according to the postoperative period at 8,21 and 49 days. One $\mathrm{mL}$ of HAP- $91^{\circledR}$, fluid and viscous, was implanted in the subcutaneous tissue, $1 \mathrm{~cm}$ proximal to the cranial crest of the right scapula. The thickness of the skin was measured before and after implantation and for the following 15 days. Pain sensitivity assessment was conducted, assigning the following scores: 0 - when the animal allowed the touch of the implant area and expressed no signs of pain; 1 - when the animal allowed the touch, but pain reaction occurred, like increase of the respiratory rate or attempt to escape; 2 - when the animal did not allow the touch to the implanted area. At 8, 21 and 49 days, biopsy of the implanted area was performed. No difference was observed between the thickness of the skin ( $p>0.05)$ and all animals received a score 0 for soreness. Histological analysis did not reveal any obvious inflammatory process, showing a predominance of mononuclear cells in samples of eight days and tissue organization around the biomaterial with a tendency to encapsulation. The results indicate that HAP-91 ${ }^{\circledR}$, both viscous and fluid, is biocompatible and suitable for dermal filling.
\end{abstract}

Key words: cutaneous implant, composite, aesthetic medicine.

\section{RESUMO}

\section{Compósito de hidroxiapatita sintética $30 \%$, em dois estados físicos, como preenchedor de relevo cutâneo}

Objetivou-se avaliar a resposta tecidual, após implantação de hidroxiapatita sintética 30\% (HAP-91 ${ }^{\circledR}$ ), em dois estados físicos, para preenchimento cutâneo. Foram utilizados 18 coelhos da raça Nova Zelândia, distribuídos aleatoriamente em dois grupos (HAP-9 $1^{\circledR}$ fluida e viscosa) e, posteriormente, divididos em três subgrupos, de acordo com o período pós-implante, em oito, 21 e 49 dias. Em cada grupo foi implantado 1,0 mL de HAP-91 ${ }^{\circledR}$, fluida ou viscosa, no tecido subcutâneo, $1 \mathrm{~cm}$ cranial à crista da escápula direita. Foi realizada a mensuração da espessura cutânea, imediatamente antes e durante 15 dias após a implantação do compósito. Avaliações de sensibilidade dolorosa foram realizadas, atribuindo-se os escores: 0 - quando o animal permitiu o toque e não manifestou reação; 1 - quando permitiu o toque, mas manifestou reação de dor, como aumento da frequência respiratória ou tentativa de fuga; 2 - quando não permitiu o toque. Aos oito, 21 e 49 dias, foi realizada a biópsia da região implantada. Não foi observada diferença entre a espessura cutânea dos animais $(\mathrm{p}>0,05)$ e todos os animais receberam escore 0 para sensibilidade dolorosa. Na análise histológica, não foi notado processo inflamatório evidente. Houve predomínio de células mononucleares, nas amostras de oito dias, e uma organização tecidual ao redor do biomaterial, com tendência ao encapsulamento. A HAP$91^{\circledR}$, tanto fluida quanto viscosa, é biocompatível e indicada para o preenchimento cutâneo.

Palavras-chave: implante cutâneo, compósito, medicina estética.

Received:14/09/2012; Accepted:09/04/2013.

${ }^{1}$ Veterinarians. Departamento de Veterinária, Universidade Federal de Viçosa, Campus Viçosa, Avenida Peter Henry Rolfs, s/n, 36570-000, Viçosa, Minas Gerais, Brazil. rodrigo.sepulveda@ufv.br; ingridbonenb@yahoo.com.br

${ }^{2}$ Veterinarians, Doctors of Science. Departamento de Veterinária, Universidade Federal de Viçosa, Campus Viçosa, Avenida Peter Henry Rolfs, s/n, 36570-000, Viçosa, Minas Gerais, Brazil. andrea@ufv.br (corresponding author); lissandro@ufv.br; fabriciovalente@gmail.com; emilycarlo@yahoo.com.br 


\section{INTRODUCTION}

There is, with aging, a reduction of endocrine secretions and narrowing of skin arterioles, affecting the metabolism of collagen, elastin and subcutaneous fat, which causes reduction in the thickness of the skin and results in loss of elasticity. As a result of the continuous movement of the face and the continuation of the process of aging, temporary wrinkles and contour alterations may become permanent (Dayan \& Bassichis, 2008; Hamilton, 2009; Redborn et al., 2011; Flynn et al., 2012; Narins et al., 2012).

Currently, the treatment of the signs associated with facial aging consists in restoring the volume and contour of the face and not just to pull the tissues, as in the past (Dayan \& Bassichis, 2008; Vargas et al., 2009). The correction of the effects of facial aging should be directed primarily to the correction of volume as, without it, the patient continues with an aged appearance. Skin fillers have become popular for this purpose because are minimally invasive and durable, showing no potential comorbidities as a surgical procedure (Smith et al., 2007; Dayan \& Bassichis, 2008; Vargas et al., 2009; Sundaram et al., 2010; Sturm et al., 2011).

The rheological properties of a dermal filler, such as viscosity and elasticity, have clinical relevance because it relates to the passage of the material through the needle, the rigidity of the filler and the ability to resist deformation as it is injected. After implantation, these properties influence the manner in which the biomaterial will resist tension forces inherent to the site in which it was deployed, for example, facial movements. When deployed in the face, the greater elasticity of the biomaterial, the better is its resistance to skin tension forces (Sundaram et al., 2010).

A number of products are approved for use in procedures for aesthetic or repairer purposes due to trauma, congenital deformities and breast cancer (Sánchez et al., 2012). Autologous fat, bovine collagen, hyaluronic acid, polymethylmethacrylate (PMMA) and hydroxyapatite (HA) are some examples (Smith et al., 2007; Vargas et al., 2009). Compound materials of autologous fat, collagen or cartilage are reabsorbed, requiring new applications in a short period of time, so the search for more durable products is necessary (Morhenn et al., 2002).

The HA has the main clinical indication for filling bone defects (Borges et al., 2000; Brandão et al., 2002; Ajdukovic et al., 2005; Scarano et al., 2006; Vital et al., 2006; Carlo Reis et al., 2011); however, its use as dermal filler is already being practiced. Its initial indication for this purpose is the assistance in the treatment of lipoatrophy associated with infection by human immunodeficiency virus (HIV) (Berlin et al., 2006; Alam \& Yoo, 2007; Feeney et al., 2009; Hornberger et al., 2009; Alam et al., 2011).
The aim of this study is to investigate the clinical and histological response to the use of $30 \%$ synthetic hydroxyapatite (HAP-91 ${ }^{\circledR}$ ), liquid and viscous, as dermal filler.

\section{MATERIALS AND METHODS}

The methodology of this study was approved by the Ethics Committee on Animal Use, of Universidade Federal de Viçosa, under the protocol 15/2012.

Eighteen New Zealand rabbits, seven months of age, weighing between 3 and $5 \mathrm{~kg}$, from the Department of Animal Science of the Universidade Federal de Viçosa were used in the experiment. The animals were separated randomly into two groups of equal sizes. The rabbits of both groups were implanted subcutaneously HAP-91 ${ }^{\circledR}$ : group 1 in the liquid form and group 2 in the viscous form. The material is composed of hydroxyapatite, water and carboxymethylcellulose, being the main difference between the two composites the proportion of carboxymethylcellulose, which is kept secret by the patent process in progress.

The animals were sedated with acepromazine $(0.1 \mathrm{mg} /$ $\mathrm{Kg}$ IM - Acepran $\left.{ }^{\circledR} 0,2 \%\right)$ and underwent shaving of the neck and part of the right hemithorax. The region chosen for implantation was the subcutaneous tissue, $1 \mathrm{~cm}$ proximal to the cranial crest of the right scapula. Both products were applied, using a $3 \mathrm{~mL}$ syringe and a 40x 8 gauge needle for the liquid form and a 40x12 gauge needle for the viscous form. The rabbits of group 1 received $1 \mathrm{ml}$ of HAP- $91^{\circledR}$ in the fluid physical state, while the group 2 received $1 \mathrm{~mL}$ of HAP- $91{ }^{\circledR}$ in the viscous physical state. Prior to product application, skin thickness was measured with a steel mechanical caliper with scale reading of 150 $\mathrm{mm}$ and $0.01 \mathrm{~mm}$.

Daily physical examination to verify the soreness and skin thickness were conducted for 15 days by the same evaluator. The soreness was analyzed by the animal's reaction to touch to the region in which the biomaterial was implanted, assigning scores: 0 - when allowed the touch and the animal did not expressed reaction, 1 - when the touch was enabled but expressed reactions of pain, such as increased respiratory rate or attempted escape; 2 - if not allowed to touch.

For biopsies, the animals were sedated with the same protocol used previously and anesthetized with a combination of tiletamine with zolazepam $(30 \mathrm{mg} / \mathrm{Kg}$ IM Zoletil $^{\circledR} 50$ ). After 8, 21 and 49 days post-implant, with the aid of a scalpel, the skin, the subcutaneous tissue and the implant was removed for histological evaluation.

The collected fragments were fixed in $10 \%$ formalin and subjected to routine histological processing being dehydrated in increasing alcohol solutions, diaphanous 
in xylene and embedded in paraffin. Sections of 7ìm were obtained from each sample and stained with hematoxylin and eosin.

On histological analysis, the reaction of the dermis was assessed semi-quantitatively, assigning scores from one to three or zero, according to the intensity or absence of the evaluated parameters, respectively. Thus, it was obtained the variations of polymorphonuclear, lymphocytic and histiocytic infiltrates as well as the presence of hyperemia and necrosis. Additionally, we performed a descriptive analysis of the tissue reaction to the biomaterial, verifying the type of tissue infiltrates between the particles, the presence of vascularization, capsule formation and level of material degradation.

The data obtained in the evaluation of pain sensitivity were tested using the Mann-Whitney test and skin thickness was evaluated by ANOVA. The histomorphometric data were analyzed using the nonparametric Kruskal-Wallis test followed by Dunn's test when the $p$ value was significantly different in the first analysis. For all tests, we considered the significance of $5 \%$. BioStat 5.0 and SigmaPlot 11.0 were used for statistical analysis.

\section{RESULTS AND DISCUSSION}

During the studied period, all animals received score 0 in the evaluation of pain sensitivity, both for fluid and viscous HAP- $91^{\circledR}$, indicating that it was a slightly painful medical procedure. This result was observed during the implantation of the product, since the animals tolerated the procedure with only a light tranquilization provided by acepromazine. A similar result, in dogs, was reported by Carlo et al. (2007) following implantation of HAP-91 ${ }^{\circledR}$ and bioglass particles in the subcutaneous tissue and by Marmur et al. (2010) in a study on the occurrence of pain after HA implantation for the correction of nasolabial defects in humans.

The occurrence of pain is one of the possible complications associated with the use of $\mathrm{HA}$ as a dermal filler (Vargas et al., 2009); however, with the use in humans, the pain is more related to physical factors such as the size of needle used and speed of deployment than with adverse reactions of the product (Alam et al., 2011).

During implantation of viscous HAP-91 ${ }^{\circledR}$, it was used a caliber needle, in view of the difficulty of injecting the material at the proposed site, which is consistent with the rheological properties cited by Sundaram et al. (2010). Nevertheless, no difference was observed in the behavior of animals during implantation and no difference in the clinical analysis, being the property of the biomaterial at the predetermined times of no relevance for the dermal filling.
During the 15 days of observation, there was no difference in skin thickness of the animals before and after implantation of the material ( $p>0.05$ ) (Figure 1). In all animals, there was formation of a small palpable nodule in the subcutaneous tissue, which remained unchanged over the period, as reported by Carlo et al. (2007) for granules of HA. Alam et al. (2011) showed the permanence of the implant for up to 15 months and Vargas et al. (2009) described a period from 9 to 18 months, featuring the HA implant as semipermanent. Although Vargas et al. (2009) assert that the HA has a smooth surface and therefore it is encapsulated with fibrous tissue, escaping phagocytosis, the HA used is porous, presenting micro and nanopores, facilitating the interaction between tissues and decreasing the possibility of migration of the implant (Carlo Reis et al., 2012). Semipermanent implants require new sessions of application of the product after its absorption, however, are they superior to permanent implants for not having intense foreign body reaction. Nevertheless, until the mechanisms of granuloma formation are fully understood, it is not possible to predict its late formation (Alam \& Yoo, 2007; Vargas et al., 2009; Alam et al., 2011).

The histological analysis showed that the biomaterial could be identified as a heterogeneous mass, acellular, well-defined, predominantly basophilic, but with obvious gray elements, which showed no affinity for any of the two dyes used, being denser in the group with fluid HAP$91^{\circledR}$. This may be linked with the presence of carboxymethylcellulose.

There was no statistical difference between the groups and the samples also showed no significant inflammation and no evidence of necrosis.

In one sample of the group with fluid HAP- $91^{\circledR}$, which was collected at 49 days, there was bleeding, especially in the space between the capsule and cell proliferation

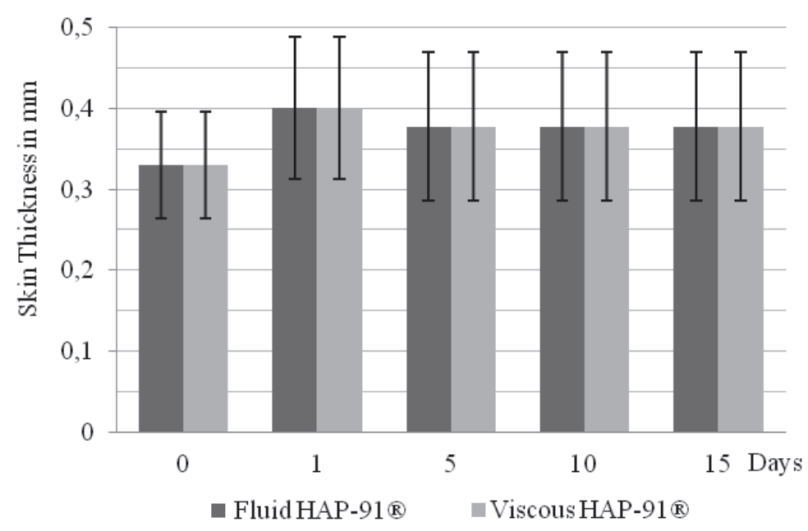

Figure 1. Mean and standard deviation of the skin thickness in millimeters (mm) immediately before (day 0 ) and on days 1,5 , 10 and 15 after implantation of HAP- $91^{\oplus}$ on two physical states in the evaluation of its effect as a dermal filler. 
through the area that the biomaterial was deposited. The bleeding may have been caused by the rupture of newly formed vessels in a process of neovascularization or caused by the collection of the material. There was no bleeding in the dermis, but hyperemia, however, the values were shown to be variable and showed no statistical difference $(p=0.201)$.

Only one animal of the group with fluid HAP $-91^{\circledR}$ at 8 days showed intense infiltration of polymorphonuclear cells in the dermis, however, there was no difference between groups $(\mathrm{p}=0.502)$ indicating that it is probably an individual reaction. Lymphocytic infiltrate was also observed in the dermis of two samples of this group, yet there was no statistical difference between the groups ( $p$ $=0.098$ ). Just one sample of the group with viscous HAP$91^{\circledR}$, collected at 49 days, showed nodular lymphocytic inflammatory infiltrate, and this finding was probable an individual response.

The Kruskal-Wallis test revealed a significant difference for the histiocytic infiltrate $(p=0.020)$ between groups, and although the Dunn's test failed to identify in which pairs is the difference, it is clear that the infiltrate was intense in the dermis of samples taken at eight days. These groups had a median value to 3 , while all others showed 0 . This may be due to trauma associated with the implantation of the composite and/or minor abrasions resulting from shaving carried out on the site, since the values median decrease with respect to time, with value 0 in samples 49 days post-implantation.

In samples with eight days after implantation, cell invasion can be observed in and through the composite forming an interaction interface between the composite and adjacent tissue (Figure 2); however, the organization of the connective tissue around the composite was still disordered, scattered and absent in some areas. This interface, comprising portions of the biomaterial isolated by cellular organization, grew thicker with time.

Also at eight days, it was observed the presence of eosinophil infiltration in a sample while the blood vessels in the surrounding tissue reaction did not show prominent exudative inflammatory vascular events. Escobar \& Jaramillo (2009) described eosinophilic infiltration as part of the initial inflammatory process in response to the presence of the biomaterial in a study on the preparation of a folder bone of HA. It is known that eosinophil infiltrate reactions are associated with type I hypersensitivity mediated by $\operatorname{IgE}$ and is characterized clinically by erythema, swelling, itching and/or heat (Averbeck et al., 2007). Kari et al. (2010) stated that eosinophils and mast cells play an important role in allergic processes, however, they also have pro-inflammatory properties. Since none of the animals showed clinical signs of allergic process and were not observed histological signs of vasculitis or exudative cases, it is possible that the infiltration is part of the normal inflammatory response to the implant in the subcutaneous tissue of the composite.

In samples with 21 days after implantation, it was noted the presence of giant cells, blood vessels and connective tissue proliferation with collagen deposition (Figures 3A e B). These observations are also valid for the samples collected at 49 days post-implantation, but cell proliferation was more evident at this time (Figures 4A and $\mathrm{B}$ ). The formation of a connective tissue capsule was progressive between sampling dates and was more intense on the opposite side to the epidermis. The fibrous capsule formation is related to a number of factors such as the size, shape and texture of the implant as well as its chemical properties, porosity, deployment location, and the physical and chemical stimuli caused by the implant, being an expected response to the material within the normal range (Li et al., 1999; Carlo et al., 2007; Qu et al., 2010; Khashaba et al., 2011). According to Xavier et al. (2002), it is likely that this capsule prevents the leakage of the biomaterial, therefore reducing the inflammatory response near the site of application and thereby reducing the occurrence of granulomas.

Until the last collection, the presence of the biomaterial could be verified in histological samples (Figure 4). One of the goals when using biodegradable materials is to replace the material used by the body's own cells, over time (O'Brien, 2011). Xie et al. (2012) commented that the biodegradability, at controlled levels, is an important characteristic related to biomaterials, especially with those implanted in bone tissue, because there must be degradation of the biomaterial as the new tissue is formed.

Materials used for permanent skin filling are often required for a new application, since the skin structures still suffer the effects of gravity and the aging process and the overlap of another filler may increase under the skin in an unaesthetic way causing an unnatural result.

Although it is still possible to note the presence of the composite at 49 days, decrease of its presence in the implanted area, displayed by portions of the composite getting smaller, indicate that HAP- $91{ }^{\circledR}$ has advantageous features of biodegradability for dermal filling.

These results indicated a predominance of mononuclear cells in samples from eight days and tissue organization around the biomaterial with tendency for encapsulation with ever-smaller portions of HAP-91 ${ }^{\circledR}$, as well as fibrous capsule formation and mild inflammatory reaction, being observed in samples from 21 and 49 days, as reported by Li et al. (1999), Xavier et al. (2002), Berlin et al. (2006), Carlo et al. (2007), Dayan \& Bassichis (2008), Vogt et al. (2008), Jones (2009), Qu et al. (2010) and Khashaba et al. (2011). 


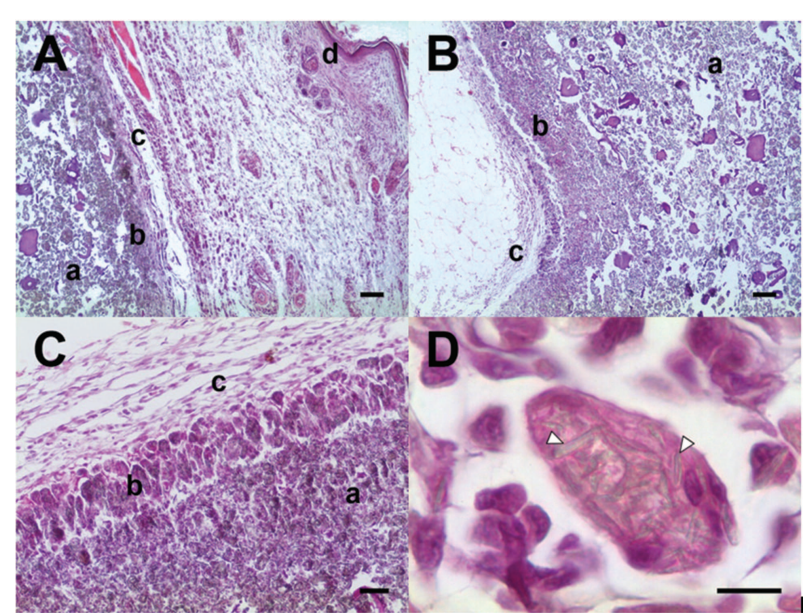

Figure 2. Photomicrographs of tissue reaction after eight days of subcutaneous implantation of hydroxyapatite in rabbits. Note that in $\mathrm{A}$ and $\mathrm{B}$, the interaction interface between the biomaterial and surrounding tissue in the viscous form (40x - 100 micron bar). In $C$, tissue reaction in an animal of the fluid group (100x bar $50 \mu \mathrm{m}$ ) and $\mathrm{D}$ the composite, in its viscous form, phagocytosed (1000x - bar $10 \mu \mathrm{m}$.) Observing the deposit of the biomaterial (a) tissue interaction interface with the biomaterial (b) organization area of the capsule (c) the epidermis (d) and fragments of the biomaterial (arrow heads).

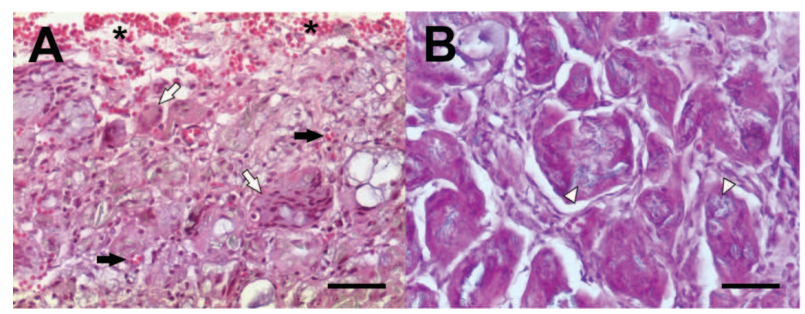

Figure 3. Photomicrographs of tissue reaction after 21 days of subcutaneous implantation of hydroxyapatite in rabbits. Note the tissue reaction of viscous HAP- $91^{\circledR}$ in A and the fluif HAP$91^{\circledR}$ in B $(200 \mathrm{x}$ - bar $50 \mu \mathrm{m})$. Area of hemorrhage (asterisk); newly formed blood vessels (black arrow); biomaterial (white arrow head) and giant cells (white arrow).

These findings indicate that HA is not inert, as also reported by Sánchez et al. (2012), and, at first, cause an inflammatory reaction, which is characterized by diffuse infiltration of mononuclear and polymorphonuclear cells. It was also observed a trend toward cellular and tissue organization around the biomaterial with the time, with a view to the progressive formation of a fibrous capsule. There is no evidence of intense foreign body reaction related to the presence of the composite, as well as evidence of necrosis and toxicity. According to Williams (2008), biocompatibility refers to the characteristic of a material that, when in contact with any living tissue, causing an expected, non-toxic reaction, with no damage to the host and with preservation of the function of both the material and the tissue. Qu et al. (2010) reported that the biocompatibility evaluation should be performed in

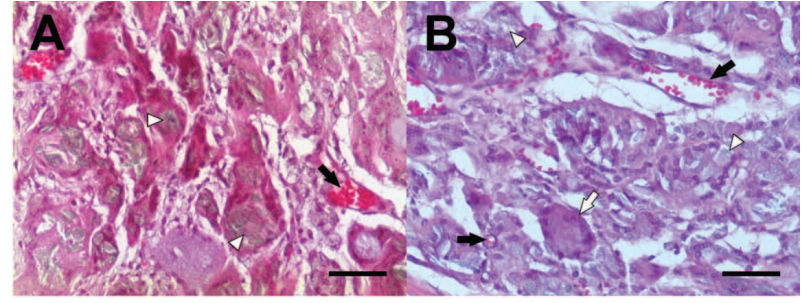

Figure 4. Photomicrographs of tissue reaction after 49 days of subcutaneous implantation of hydroxyapatite in rabbits. Note the tissue reaction of HAP- $91{ }^{\circledR}$ in its viscous form in A and in its fluid form in B (200x - bar $50 \mu \mathrm{m})$. Newly formed blood vessels (black arrow); biomaterial (white arrow head) and giant cells (white arrow).

at least three stages: acute, one week after implantation of the biomaterial; transient, after one month of implantation and chronic, after eight weeks of implantation. In this study, the maximum histological observation was carried out at seven weeks and no signs of necrosis, toxicity, suppuration or rejection of the implant was observed. However, for evaluating the effectiveness of HAP- $91^{\circledR}$ on skin filling, a longer period of observation is required since the HA is considered a semi-permanent implant, and it was reported that the residence period in the tissue is up to 18 months (Vargas et al., 2009; Alam et al., 2011). It is expected that even with a longer observation time, HAP- $91{ }^{\circledR}$ shows no signs that impede its use as a dermal filler.

\section{CONCLUSIONS}

The HAP- $91^{\circledR}$, both viscous and fluid, is well tolerable for subcutaneous implantation, as it causes little painful reaction. Compared with the viscous HAP-91 ${ }^{\circledR}$, the fluid HAP- $91{ }^{\circledR}$ is easier for implantation. The HAP- $91{ }^{\circledR}$ has no histologically signs of toxicity, promoting discrete initial inflammatory response to their presence, with a tendency to encapsulation. HAP- $91^{\circledR}$ is biodegradable and biocompatible. However, as it is a semi-permanent implant, a longer period of evaluation may be needed.

\section{ACKNOWLEDGEMENTS}

The authors thank JHS Laboratório Químico Ltda., FAPEMIG (Fundação de Amparo à Pesquisa no Estado de Minas Gerais) and CNPq (Conselho Nacional de Desenvolvimento Científico e Tecnológico) for the financial support.

\section{REFERENCES}

Ajdukovic Z, Najman S, Dordevi D, Savic V, Mihailovic D, Petrovic D, Ignjstovic N \& Uskokovic D (2005) Repair of bone tissue affected by osteoporosis with hydroxyapatite-poly-lactide (HAPLLA) with and without blood plasma. Journal of Biomaterials Applications, 20:179-190. 
Alam M \& Yoo SS (2007) Technique for calcium hydroxylapatite injection for correction of nasolabial fold depressions. Journal of the American Academy of Dermatology, 56:285-289.

Alam M, Havey J, Pace N, Pongprutthipan M \& Yoo SS (2011) Large-particle calcium hydroxylapatite injection for correction of facial wrinkles and depressions. Journal of the American Academy of Dermatology, 65:92-96.

Averbeck M, Gebhardt C, Emmirich F, Treudler R \& Simon JC (2007) Immunologic principles of allergic disease. Journal of German Society of Dermatology, 5:1015-1028.

Berlin A, Cohen JL \& Goldberg DJ (2006) Calcium hydroxylapatite for facial rejuvenation. Seminars in Cutaneous Medicine and Surgery, 25:132-137.

Borges APB, Rezende CMF, Ribeiro MFB, Melo EG \& Neto PIN (2000) Hidroxiapatita sintética como substituto ósseo em defeito experimental provocado no proximal da tíbia de cão: aspectos à microscopia de transmissão. Arquivo Brasileiro de Medicina Veterinária e Zootecnia, 52:616-620.

Brandão AC, Brentegani LG, Novaes AB, Grisi MFM, De Souza SLS, Taba Junior M \& Salata LA (2002) Histomorphometric analysis of rat alveolar wound healing with hydroxyapatite alone or associated to BMPs. Brazilian Dental Journal, 13:147-154

Carlo EC, Borges APB, Rezende CMF, Moreira JCL, Fonseca CC, Pontes KCS \& Duarte TS (2007) Avaliação do efeito osteoindutor da hidroxiapatita e do biovidro implantados em tecido subcutâneo de cão. Revista Ceres, 54:492-500.

Carlo Reis EC, Borges APB, Araújo MVF, Mendes VC, Guan L \& Davies JE (2011). Periodontal regeneration using a bilayered PLGA/calcium phosphate construct. Biomaterials, 32:92449253.

Carlo Reis EC, Borges APB, Oliveira PM, Bicalho SMCM, Reis AM \& Da Silva CL (2012) Desenvolvimento e caracterização de membranas rígidas, osteocondutoras e reabsorvíveis de polihidroxibutirato e hidroxiapatita para regeneração periodontal. Polímeros 22:1-7.

Dayan SH \& Bassichis BA (2008) Facial dermal fillers: selection of appropriate products and techniques. Aesthetic Surgery Journal, 3:335-347.

Escobar DM \& Jaramillo C (2009) Preparation and evaluation of a bone paste for medical applications. Revista Faculd de Ingeniería de Universidad de Antiquia, 49:151-159.

Feeney JN, Fox JJ \& Arkhust T (2009) Radiological impact of the use of calcium hydroxylapatite dermal fillers. Clinical Radiology, 64:897-902.

Flynn TC, Carruthers A, Carruthers J, Geister TL, Görtelmeyer R, Hardas B, Himmrich S, Kerscher M, De Maio M, Mohrmann C, Narins RS, Pooth R, Rzany B, Sattler G, Buchner L, Benter U, Fey C \& Jones D (2012) Validated assessment scales for the upper face. Dermatologic Surgery, 38:309-319.

Hamilton TK (2009) Skin augmentation and correction: the new generation of dermal fillers - a dermatologist's experience. Clinics in Dermatology, 27:13-22.

Hornberger J, Rajagopalan R, Shewade A \& Loutfy MR (2009) Cost consequences of HIV-associated lipoatrophy. AIDS Care, $21: 664-671$.

Jones DH (2009) Semipermanent and permanent injectable fillers. Dermatologic Clinics, 27:433-444.

Kari O, Haahtela T, Laine P, Turunen JP, Kari M, Sarna S, Laitinen T \& Kovanen PT (2010) Cellular characteristics of nonallergic eosinophilic conjunctivitis. Acta Ophthalmologica, $88: 245-250$.
Khashaba RM, Moussa MM, Chutkan NB \& Borke JL (2011) The response of subcutaneous connective tissue to newly developed calcium phosphate-based root canal sealers. Internacional Endodontic Journal, 44:342-352.

Li D, Ohsaki K, Ii K, Cui P, Ye Q, Baba K, Wang Q, Tenshin S \& Takano-Yamamoto T (1999) Thickness of fibrous capsule after implantation of hydroxyapatite in subcutaneous tissue in rats. Journal of Biomaterials Research, 15:322-326.

Marmur E, Green L \& Busso M (2010) Controlled, randomized study of pain levels in subjects treated with calcium hydroxylapatite premixed with lidocaine for correction of nasolabial folds. Dermatologic Surgery, 36:309-315.

Morhenn VB, Lemperle G \& Gallo RL (2002) Phagocytosis of different particulate dermal filler substances by human macrophages and skin cells. Dermatologic Surgery, 28:484-490.

Narins RS, Carruthers J, Flynn TC, Geister TL, Görtelmeyer R, Hardas B, Himmrich S, Jones D, Kerscher M, De Maio M, Mohrann C, Pooth R, Rzany B, Sattler G, Buchner L, Benter U, Breitscheidel L \& Carruthers A (2012) Validated assessment scales for the lower face. Dermatologic Surgery, 38:333-342.

O'Brien FJ (2011) Biomaterials \& scaffolds for tissue engineering. Materials Today, 14:88-95.

Qu Y, Wang P, Man Y, Li Y, Zuo Y \& Li J (2010) Preliminary biocompatible evaluation of nano-hydroxyapatite/polyamide66 composite porous membrane. Internacional Journal of Nanomedicine, 5:429-435

Redborn KP, Busso M \& Hanke CW (2011) Soft-tissue augmentation with hyaluronic acid and calcium hydroxyl apatite fillers. Dermatologic Therapy, 24:71-81.

Sánchez O, Rodríguez-Sureda V, Domínguez C, Fernadéz-Figueras T, Vilches A, Llurba E \& Alijotas-Reig J (2012) Study of biomaterial-induced macrophage activation, cell-mediated immune response and molecular oxidative damage in patients with dermal bioimplants. Immunobiology, 217:44-53.

Scarano A, Degidi M, Iezzi G, Pecora G, Piattelli M, Orsini G, Caputi S, Perrotti V, Mangano C \& Piattelli A (2006) Maxillary sinus augmentation with different biomaterials: a comparative histologic and histomorphometric study in man. Implant Dentistry, 15:197-207.

Smith S, Busso M, McClaren M \& Bass LS (2007) A randomized, bilateral, prospective comparison of calcium hydroxylapatite microspheres versus human-based collagen for the correction of nasolabial folds. Dermatologic Surgery, 33:112-121.

Sturm LP, Cooter RD, Mutimer KL, Graham JC \& Maddern GJ (2011) A systematic review of dermal fillers for age-related lines and wrinkles. ANZ Journal of Surgery, 81:9-17.

Sundaram H, Voigts B, Beer K \& Meland M (2010) Comparison of the rheological properties of viscosity and elasticity in two categories of soft tissue fillers: calcium hydroxylapatite and hyaluronic acid. Dermatologic Surgery, 36:1859-1865.

Vargas AF, De Amorim NC \& Pintaguy I (2009) Complicações tardias dos preenchimentos permanentes. Revista Brasileira de Cirurgia Plástica, 24:71-81.

Vital CC, Borges APB, Fonseca CC, Tsiomis AC, Carvalho TB, Fontes EB, Sena MP \& Fófano G (2006) Biocompatibilidade e comportamento de compósitos de hidroxiapatita em falha óssea na ulna de coelhos. Arquivo Brasileiro de Medicina Veterinária Zootecnia, 58:175-183.

Vogt JC, Brandles G, Krüger I, Behrens P, Nolte I, Lenarz T \& Stieve M (2008) A comparison of different nanostructured biomaterials in subcutaneous tissue. Journal of Material Science: Materials in Medicine, 19:2629-2636. 
Williams D (2008) On the mechanisms of biocompatibility. Biomaterials 29:2941-2953.

Xavier AP, Schellini SA, Aragon FF, Padovani CR \& Taga EM (2002) Short-term evaluation of non-absorbable microgranular hydroxyapatite infiltration in the guinea pig subepidermal abdominal region. Brazilian Journal of Medical and Biological Research, 35:69-73.
Xie H, Wang Q, Ye Q, Wan C \& Li L (2012) Application of K/Sr co-doped calcium polyphosphate bioceramic as scaffolds for bone substitutes. Journal of Material Science: Materials in Medicine, publicado online em 05 de fevereiro de 2012. Available at: < http://www.springerlink.com/content/rv38x01038t78417/ fulltext.pdf $>$. Accessed on: February 09, 2012. 